\title{
YIELD, PHYSIOLOGICAL QUALITY AND CHEMICAL COMPOSITION OF PHASEOLUS VULGARIS SEEDS, PRODUCED IN THE STATE OF RIO GRANDE DO SUL, BRAZIL
}

\author{
Tiago Pedó1, Angelita Celente Martins ${ }^{1}$, Dominique Dos Santos Delias², Emanuela Garbin \\ Martinazzoํㅜ, Vinícius Jardel Szareski ${ }^{1}$, Ivan Ricardo Carvalho², Francine Lautenchleger ${ }^{1}$, Velci \\ Queiróz de Souza1, Tiago Zanatta Aumonde¹, Francisco Amaral Villela1.
}

\begin{abstract}
${ }^{1}$ Federal Universidade of Pelotas - Doctorate in Seed science and technology. Avenida Eliseu Maciel, s/n - 96001-970 Capão Leão, RS-Brazil. ; ${ }^{2}$ Department of Agrarian studies, Regional Northwest University of Rio Grande do Sul - Post doctoral in crop plants and seed science and technology. 3000 Comércio Street, ljuí, RS, 98700-000, Brazil. E-mail: carvalho.irc@gmail.com
\end{abstract}

ABSTRACT: The objective of this study was to evaluate the yield and physiological quality of bean seeds in two agricultural crops, and the chemical composition of seedlings submitted to adverse temperatures during germination. For the field experiment, a randomized block design was used, using five genotypes, BRS Embaixador, IPR Tuiuiú, Guabiju, Carioquinha and Mouro, arranged in four replicates. The experimental units were composed of five lines with five meters in length, where 25 plants were randomly collected per experimental unit to measure the characters of interest. For laboratory testing the seeds produced were submitted to three temperatures $\left(15,25\right.$ and $\left.35^{\circ} \mathrm{C}\right)$ during germination under controlled conditions. The evaluated characters were: grain yield, mass of a thousand seeds, germination, first germination count, starch content, soluble sugar, soluble protein and total amino acids. The data were submitted to analysis of variance and later compared by the Tukey test. Yield per plant revealed changes between the agricultural crops, as well as among the genotypes tested. Germination and the first germination count revealed higher magnitudes in seeds produced by BRS Embaixador, IPR Tuiuiu and Carioquinha genotypes. Yield, seed physiological quality and chemical composition of seedlings are influenced by the crop and genotypes tested.

Key Words: Germination, starch, protein, soluble sugar, amino acids.

RENDIMENTO, QUALIDADE FISIOLÓGICA E COMPOSIÇÃO QUÍMICA DAS SEMENTES DE PHASEOLUS VULGARIS, PRODUZIDAS NO ESTADO DO RIO GRANDE DO SUL, BRASIL

RESUMO: O objetivo deste trabalho foi avaliar o rendimento e a qualidade fisiológica de sementes de feijão em duas culturas agrícolas e a composição química de mudas submetidas a temperaturas adversas durante a germinação. 
Para o experimento de campo, utilizou-se o delineamento de blocos casualizados, utilizando cinco genótipos, BRS Embaixador, IPR, Tuiuiú, Guabiju, Carioquinha e Mouro, dispostos em quatro repetições. As unidades experimentais foram compostas por cinco linhas com cinco metros de comprimento, onde 25 plantas foram coletadas aleatoriamente por unidade experimental para medir os caracteres de interesse. Para testes laboratoriais, as sementes produzidas foram submetidas a três temperaturas $\left(15,25\right.$ e $\left.35^{\circ} \mathrm{C}\right)$ durante a germinação sob condições controladas. Os caracteres avaliados foram: rendimento de grãos, massa de mil sementes, germinação, primeira contagem de germinação, teor de amido, açúcar solúvel, proteína solúvel e aminoácidos totais. Os dados foram submetidos à análise de variância e posteriormente comparados pelo teste de Tukey. O rendimento por planta revelou mudanças entre as culturas agrícolas, bem como entre os genótipos testados. A germinação e a primeira contagem de germinação revelaram maiores magnitudes nas sementes produzidas pelos genótipos BRS Embaixador, IPR Tuiuiu e Carioquinha. O rendimento, a qualidade fisiológica das sementes e a composição química das plântulas são influenciados pela cultura e genótipos testados.

Palavras-chave: Germinação, amido, proteína, açúcar solúvel, aminoácidos.

Abbreviation: $T_{-}$average air temperature; $\mathrm{RH}_{-}$relative air humidity; $\mathrm{SR}$ solar radiation incident; M1000_ mass of 1000 seeds; $Y_{-}$seed yield per plant, $G_{-}$

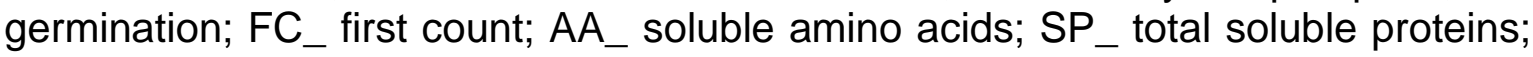
SS_total soluble sugars; SC_ starch.

\section{INTRODUCTION}

The increase in the intensity of climatic adversities has generated the demand for adapted and more productive genotypes for each microclimate. The positioning of genotypes with a higher level of adaptation to periods of stress is fundamental for the maintenance and increase of agricultural production. The use of more efficient management techniques and higher-quality seeds is the first step in obtaining superior yields and high-quality seeds (ALBRECHT et al., 2009; PESKE et al., 2012).

In Brazil, beans of the species Phaseolus vulgaris $\mathrm{L}$. is one of the main crops, with the national production of the grain in the 2018/2019 crop exceeding 3,395 thousand tons and the average yield in the State of Rio Grande do Sul of $1.7 \mathrm{tha}^{-1}$ (CONAB, 2019). The cultivation environment has a significant influence on the development and yield of cultivated plants (LACERDA et al., 2010; THUZAR et al., 2010). Daily temperatures below or above the optimum of each species should be 
considered as adverse factors and at plant development stages as one of the main limiting crop yields (THUZAR et al., 2010). In addition, there is variation among crops with regard to edaphoclimatic factors, such as solar radiation, relative air humidity, rainfall regime and level of nutrient utilization in the soil solution (PESKE et al., 2012).

Seed yield is dependent on the number of branches during vegetative growth and number of pods per plant, and these are influenced by temperature (THUZAR et al., 2010). The ideal temperature for the development of bean plants is approximately $21^{\circ} \mathrm{C}$ (CTSBF, 2012). Temperatures below and above the ideal reduce the quality of the seeds produced.

In the southern region of Brazil, temperature changes throughout the year are frequent. During the winter and early spring they tend to be low, while in the summer and early fall, to be elevated. These variations may cause reduction in the physiological quality of seeds (SILVA et al., 2006). High temperatures result in physiological implications on pollen grains development and pollen tube growth, which may negatively affect fertilization and embryonic development (THUZAR et al., 2010). In addition, if below optimum, they may impair the establishment of seedlings (MATHEUS; LOPES, 2009) and delay the reorganization of the cell membrane system and seedling growth (PESKE et al., 2012).

The stress-inducing cultivation environment may alter plant metabolism and reduce leaf area formation (SHAO et al., 2008), the yield of the plants and modify the level and quality of the compounds present in the seeds (ALBRECHT et al., 2009). In addition, it is possible to promote the elevation of reactive oxygen species in the plants and to trigger oxidative stress (SHAO et al., 2008), reducing the physiological quality of the seeds (BEWLEY et al., 2013).

Seed vigor involves a set of cytological, biochemical and physiological processes related to the reorganization of the cell membrane system, the metabolization and the utilization of the assimilates stored in the seed, as the greater the vigor, the greater the reorganization efficiency of the cellular structures and the use of the reserve compounds (BEWLEY et al., 2013). In this sense, the evaluation of the yield, the physiological quality of seeds through the joint use of usual quality tests and the determination of the chemical composition of the resulting seedlings, 
constitutes an important tool for a better understanding of the effect of the environment on attributes of the physiological performance of bean seeds.

The objective of this study was to evaluate the yield and physiological quality of bean seeds in two agricultural crops, and the chemical composition of seedlings submitted to adverse temperatures during germination.

\section{MATERIALS AND METHODS}

\section{Seed production under field conditions}

The seeds were produced in the agricultural crops of 2013/2014 and 2014/2015, in the municipality of Ametista do Sul, situated at Latitude $27^{\circ} 20^{\prime} 20.98$ "S and Longitude $53^{\circ} 11^{\prime} 5.32$ " W in the State of Rio Grande do Sul, Brazil. The climate is classified as temperate with well distributed rains and with hot summer, being of the type Cfa by the classification of Köppen.

The experimental design was randomized blocks, with five bean genotypes (BRS Embaixador, IPR Tuiuiú, Guabiju, Carioquinha and Mouro) and two agricultural crops (2014 and 2015), arranged in four replicates.

The experimental units were composed of five rows of five meters in length, where 25 plants per experimental unit were randomly collected for evaluation of yield components and physiological quality.

The management used was as recommended for the crop in the state of Rio Grande do Sul, Brazil, and control of insect pests and diseases, carried out in a preventive manner.

The data of air temperature, relative air humidity and solar radiation were obtained from the bulletin of the Agroclimatological Station of the Federal University of Santa Maria, Frederico Westphalen-RS campus, located in the region of Ametista do Sul (Table 1). 
Table 1. Average air temperature $(T)$, relative air humidity $(\mathrm{RH})$ and solar radiation $(\mathrm{SR})$ incident on Ametista do Sul - RS. Source: UFSM Campus of Frederico Westphalen, 2014.

Tabela 1. Temperatura média do ar (T), umidade relativa do ar (UR) e radiação solar (SR) incidentes em Ametista do Sul - RS. Fonte: Campus Frederico Westphalen da UFSM, 2014.

\begin{tabular}{cccccc}
\hline \multirow{2}{*}{ Months } & \multicolumn{3}{c}{$\mathrm{T}\left(^{\circ} \mathrm{C}\right)$} & \multicolumn{2}{c}{$\mathrm{RH}(\%)$} \\
\cline { 2 - 5 } & Maximum & Minimum & Maximum & Minimum & $\left(\mathrm{kJ} \mathrm{m}^{-2}\right)$ \\
\hline October & 20.08 & 18.68 & 74.91 & 68.48 & 907.29 \\
November & 23.18 & 21.76 & 70.74 & 64.42 & 1093.42 \\
December & 24.76 & 23.22 & 75.09 & 67.72 & 1177.24 \\
\hline & \multicolumn{5}{c}{ Harvest 2014/2015 } \\
\hline Ocotober & 22.48 & 21.02 & 72.71 & 65.75 & 976.66 \\
November & 22.97 & 21.55 & 71.98 & 65.00 & 1001.65 \\
December & 23.70 & 22.47 & 77.17 & 71.36 & 978.33 \\
\hline
\end{tabular}

The seeds were harvested at $16 \%$ of moisture and submitted to natural drying, up to $13 \%$. Harvesting and processing were done manually with a sieve set of round and oblong holes, removing inert material and seeds with signs of damage. The storage of the seeds of the different genotypes was done in a cold and dry chamber $\left(10^{\circ} \mathrm{C} / 45 \%\right)$ until the physiological tests were performed.

For the yield evaluation, the following measurements were made:

Seed yield per plants $(\mathrm{Y})$ : Determined the mass of seeds produced per plant, being expressed in grams.

Mass of one thousand seeds (M1000): Obtained from the use of eight samples of 100 seeds per genotype, the results being expressed in grams (BRASIL, 2009).

\section{Physiological quality assessment}

The analyzes of physiological quality and chemical composition were performed in the Laboratory of Seed Physiology of the Postgraduate Program in Seed Science and Technology of the Faculty of Agronomy Eliseu Maciel, Federal University of Pelotas.

The seeds obtained in the field experiment were submitted to three temperatures $\left(15,25\right.$ and $\left.35^{\circ} \mathrm{C}\right)$ during the germination test. According Ecco et al. (2017) to extreme temperatures of $10^{\circ}$ and $35^{\circ} \mathrm{C}$ proportion with less number of germination seeds.

Germination test $(\mathrm{G})$ : carried out in four samples of 50 seeds, arranged to germinate in rolls formed by three germitest germination paper sheets, moistened 
with distilled water in the amount 2,5 times the dry mass of the dry paper. The rolls were transferred to B.O.D. germinating chambers, regulated at temperatures of 15; 25 and $35 \stackrel{\circ}{\circ}$ and with luminous period of $12 \mathrm{~h}$. The evaluations were carried out nine days after sowing and the results expressed as percentage of normal seedlings (BRASIL, 2009).

First germination count $(\mathrm{FC})$ : conducted together with the germination test, with evaluation at 5 days after sowing, according to the Rules for Seed Analysis (BRASIL, 2009). The results were expressed as percentage of normal seedlings.

\section{Evaluation of chemical composition}

The evaluation of the chemical composition was carried out only in seeds from the 2014 harvest, and the following characters were evaluated:

Starch content: Determined from fresh samples of plant tissue collected in all seedlings nine days after sowing, using the methodology proposed by Mc Cready et al. (1950). The values were compared to the standard glucose curve and the results expressed in $\mu \mathrm{g}$ of starch $\mathrm{g}^{-1}$ of seedlings.

Soluble sugar: The quantification of total soluble sugar levels was performed from the fresh mass of seedlings collected nine days after sowing, as recommended by Clegg (1956) and the results expressed in $\mu g$ of soluble sugar per $g$ of seedling1.

Soluble protein: Determined from the fresh mass of seedlings, collected nine days after sowing and according to Bradford (1976) methodology. The values obtained were compared with the standard curve obtained with BSA and the results expressed in $\mu \mathrm{g}$ of soluble protein $\mathrm{g}-1$ of seedling.

Total amino acids: total amino acid quantification was performed from the fresh mass of seedlings, collected nine days after sowing, as recommended by Bruening et al. (1970).

\section{Statistical analysis}

The data were submitted to analysis of individual variance for each genotype and agricultural crop, in order to identify if the model met the assumptions (RAMALHO et al., 2000). Subsequently the significant data by the $F$ test were 
compared by the Tukey test, at $5 \%$ of error probability using the Genes statistical program.

\section{RESULTS AND DISCUSSION}

From the analysis of the results it was observed that there was interaction between harvests and beans genotypes when considering the attributes mass of 1000 seeds quality, yield per plant and first count. For the seeds submitted to the different temperatures, there was interaction for germination, first germination count, total amino acids and soluble protein levels (Tables 2, 3 and 4).

The mass of 1000 seeds differed significantly between the harvests and between genotypes (Table 2). The 2013/14 harvest plants presented the superior results for the mass of 1000 seeds in the beans genotypes of IPR Tuiuiú, Guabiju, Mouro and Carioquinha. However, the genotype BRS Embaixador reached the highest mass of 1000 seeds in the 2014/2015 harvest compared to 2013/2014. It is evidenced that the BRS Embaixador allocated a greater amount of assimilates in the seeds and the genotype IPR Tuiuiú less, compared to the others independently of the harvest (Table 2).

Table 2. Mass of 1000 seeds (M1000), seed yield per plant (Y), germination (G) and first count (FC) in beans genotypes grown in the 2013/2014 and 2014/2015 harvests in the Municipality of Ametista do Sul - RS. UFPel,

Pelotas, 2017.

Tabela 2. Massa de 1000 sementes (M1000), rendimento de sementes por planta (Y), germinação (G) e primeira contagem (FG) em genótipos de feijão cultivados nas safras 2013/2014 e 2014/2015 no Município de Ametista do Sul - RS. UFPel, 2017.

\begin{tabular}{|c|c|c|c|c|c|c|c|c|}
\hline \multirow{3}{*}{ Genotypes } & \multicolumn{2}{|c|}{ M1000 (g) } & \multicolumn{2}{|c|}{$Y(g)$} & \multicolumn{2}{|c|}{ G (\%) } & \multicolumn{2}{|c|}{ FC (\%) } \\
\hline & \multicolumn{8}{|c|}{ Harvests } \\
\hline & $13 / 14$ & $14 / 15$ & $13 / 14$ & $14 / 15$ & $13 / 14$ & $14 / 15$ & $13 / 14$ & $14 / 15$ \\
\hline BRS Embaixador & $381.5 \mathrm{aB}^{1}$ & 405.7aA & 14.1eA & $11.4 \mathrm{cB}$ & $88 \mathrm{bcA}$ & $93 a A$ & $75 b B$ & $92 a A$ \\
\hline IPR Tuiuiú & 194.1eA & $161.3 \mathrm{eB}$ & $16.4 \mathrm{cA}$ & $8.9 \mathrm{~dB}$ & $99 a A$ & $92 \mathrm{aB}$ & $92 \mathrm{aA}$ & $92 \mathrm{aA}$ \\
\hline Guabiju & $296.2 c A$ & $232.0 \mathrm{~dB}$ & $18.9 \mathrm{bA}$ & $9.9 \mathrm{~dB}$ & $93 a b A$ & $96 a A$ & $89 a B$ & $96 a A$ \\
\hline Mouro & $344.1 \mathrm{bA}$ & $341.3 \mathrm{bA}$ & $17.9 \mathrm{bA}$ & $13.1 \mathrm{bB}$ & $84 \mathrm{cB}$ & $92 \mathrm{aA}$ & $72 b B$ & $92 a A$ \\
\hline Carioquinha & $236.3 d A$ & $253.4 \mathrm{cB}$ & $25.4 a A$ & $17.4 \mathrm{aB}$ & $92 \mathrm{abA}$ & $90 \mathrm{aA}$ & $73 b B$ & $90 \mathrm{aA}$ \\
\hline CV (\%) & \multicolumn{2}{|c|}{2.05} & \multicolumn{2}{|c|}{10.05} & \multicolumn{2}{|c|}{5.63} & \multicolumn{2}{|c|}{6.22} \\
\hline
\end{tabular}

${ }^{1}$ Averages followed by the same letter, uppercase in the line and lowercase in the column, for each response variable, do not differ by Tukey test $(0.05 \%)$.

The dry matter allocation in seeds has a close relationship with the amount of assimilates produced in the photosynthesis and with its adequate partition among 
the different plant structures (LOPES; LIMA, 2015). The photosynthesis is determined by characteristics of the genotype and favorable environmental conditions of solar radiation and temperature (MITTLERAND; BLUMWALD, 2010; MA et al., 2014; BUCHANAN, 2015), while the partitioning of assimilates during the seed filling phase should prioritize carbohydrate deposition and near physiological maturity, the allocation of oligosaccharides from the raffinose series and LEA proteins (BELEYLEY et al., 2013).

The variation in mass allocation may also be related to the morphological and growth characteristics inherent to each genotype, as well as to the climatic variations among harvests (Table 1) and to the quantitative-qualitative characteristics of the available solar radiation, as well as, can be determined by the distinct use of environmental conditions (LOPES; LIMA, 2015). The yield of seeds per plant of the different genotypes was reduced in the 2014/2015 harvest (Table 2). The genotypes BRS Embaixador, IPR Tuiuiú, Guabiju, Mouro and Carioquinha presented a reduction in seed yield of $2.67 \mathrm{~g}(19 \%), 7.5 \mathrm{~g}(46 \%), 9.07 \mathrm{~g}(48 \%), 4.88 \mathrm{~g}(27 \%)$ and $8 \mathrm{~g}(32 \%)$ (Table 2). The reduction of the seed yield per plant between the harvests can be attributed to the different incident solar radiation (Table 1), the smaller number of fertile flowers and the capacity of fixing the atmospheric $\mathrm{CO}_{2}$ (BUCHANAN, 2015). It can also be due to the higher abscission rate of pods, indicating greater or less tolerance and plasticity of the genotype (LIZANA et al., 2006).

In the two harvests, the genotype Carioquinha showed higher yield, while the genotype Embaixador, in the 2013/2014 harvest, and the genotypes IPR Tuiuiú and Guabiju, in the 2014/2015 harvest, had lower yield. Carioquinha genotype, although it had a lower mass of 1000 seeds than the genotype Embaixador, presented higher yield per plant.

In the two harvests the genotype Carioquinha showed higher yield, while the lowest germination was obtained in seeds of plants of the genotype Mouro and BRS Embaixador cultivated in the 2013/2014 harvest (Table 2). In the 2014/2015 harvest, no differences were observed among the genotypes, however, when evaluating the genotype Mouro, there was production of seeds with lower germination in the 13/14 harvest compared to the $2014 / 2015$ harvest. 
The first germination count showed that the vigor of the seeds produced in different harvests was variable with the genotype (Table 2). Seeds of BRS Embaixador, Mouro and Carioquinha genotypes reached the lowest values in the 2013/2014 harvest, while in the 2014/2015 harvest there were no differences among the genotypes.

Seed vigor is related to the amount of reserves available in the early stages of development, cell reorganization capacity, and efficiency in production and utilization of energy. This attribute of the physiological quality of the seeds is defined in the field of production, by means of appropriate plant and crop management practices, harvest near physiological maturity, adequate positioning of cultivars, drying and storage in favorable conditions for the preservation of the quality of the seeds (PESKE et al., 2012).

Seed germination of the five genotypes showed a significant difference among extreme temperatures (Table 3). When analyzing the genotypes at $15^{\circ} \mathrm{C}$, seed germination was lower for the Mouro genotype, compared to the others, which were similar to each other. At $35^{\circ} \mathrm{C}$, the lowest germination was obtained in seeds of Guabiju genotype (Table 3).

Table 3. Germination (G) and first germination count (FC) in beans genotypes seeds produced in the 2013/2014 and 2014/2015 harvests in the Municipality of Ametista do Sul - RS. UFPel, Pelotas, 2017.

Tabela 3. Germinação (G) e primeira contagem de germinação (CF) em sementes de genótipos de feijão produzidas nas safras 2013/2014 e 2014/2015 no Município de Ametista do Sul - RS. UFPel, 2017.

\begin{tabular}{ccccccc}
\hline \multirow{2}{*}{ Genotypes } & \multicolumn{3}{c}{$\mathrm{G}(\%)$} & $\mathrm{FC}(\%)$ \\
\cline { 2 - 6 } & $15^{\circ} \mathrm{C}$ & $25^{\circ} \mathrm{C}$ & $35^{\circ} \mathrm{C}$ & $15^{\circ} \mathrm{C}$ & $25^{\circ} \mathrm{C}$ & $35^{\circ} \mathrm{C}$ \\
\hline BRS Embaixador & $90 \mathrm{aA}^{1}$ & $95 \mathrm{aA}$ & $93 \mathrm{aA}$ & $74 \mathrm{bB}$ & $87 \mathrm{aA}$ & $85 \mathrm{bA}$ \\
IPR Tuiuiú & $92 \mathrm{aA}$ & $92 \mathrm{aA}$ & $92 \mathrm{abA}$ & $87 \mathrm{aA}$ & $89 \mathrm{aA}$ & $92 \mathrm{aA}$ \\
Guabiju & $87 \mathrm{aA}$ & $90 \mathrm{aA}$ & $86 \mathrm{bA}$ & $77 \mathrm{bC}$ & $90 \mathrm{aA}$ & $83 \mathrm{bB}$ \\
Mouro & $75 \mathrm{bB}$ & $92 \mathrm{aA}$ & $90 \mathrm{abA}$ & $56 \mathrm{cB}$ & $87 \mathrm{aA}$ & $87 \mathrm{abA}$ \\
Carioquinha & $90 \mathrm{aB}$ & $96 \mathrm{aA}$ & $89 \mathrm{abB}$ & $79 \mathrm{bB}$ & $93 \mathrm{aA}$ & $88 \mathrm{abA}$ \\
\hline CV (\%) & 3.44 & & 3.95 &
\end{tabular}

${ }^{1}$ Averages followed by the same letter, uppercase in the line and lowercase in the column, for each response variable, do not differ by Tukey test $(0.05 \%)$.

There are cardinal temperatures of germination, among them, the optimum temperature that results in the largest number of germinated seeds in the shortest time interval (MARCOS FILHO, 2015). On the other hand, the minimum and maximum temperatures are those below or above which, no germination occurs in a relatively long period of time. The lowest values of germination at temperatures of $15^{\circ} \mathrm{C}$ and $35^{\circ} \mathrm{C}$ can be attributed to the differences in cardinal temperatures and the degree of tolerance of the genotypes (BRASIL, 2009; CTSBF 2012). Unfavorable 
temperatures may negatively affect water absorption, cell-membrane reorganization, and energy production during embryo growth resumption (BEWELEY; BLACK, 2013).

The values of the first germination count, in all genotypes, were higher at $25^{\circ} \mathrm{C}$ (Table 3). The highest results in the first germination count at $15^{\circ} \mathrm{C}$ were obtained for the Tuiuiu IPR, while the lowest values in the Mouro genotype. In the Guabiju genotype, the lowest values of the first count in the temperature of $35^{\circ} \mathrm{C}$, compared to the IPR Tuiuiu, of the same commercial group (Table 3).

According to Vanzolini et al. (2007), the first germination test count is important to determine seed vigor. The first count values may be related to a slowdown of the cellular organization (BEWLEYET al., 2013). In conditions of low temperatures, a delay in germination process and seedling development may occur (MERTZ et al., 2009). The delay of germination at low temperatures is due to the lower activity of enzymes involved in the process of resumption of growth, respiration and metabolization of reserves (BELEY; BLACK, 2013).

The determination of the chemical composition in seedlings produced by seeds of the $14 / 15$ harvest showed that the level of total soluble proteins was higher in seedlings maintained under temperatures of $15^{\circ} \mathrm{C}$ and $35^{\circ} \mathrm{C}$, except for Carioquinha (Table 4). In the beans seedlings, at the temperature of $15^{\circ} \mathrm{C}$, the genotype BRS Embaixador presented higher soluble protein content, however, at $35^{\circ} \mathrm{C}$ no differences were obtained among the genotypes (Table 4).

The sugar and nitrogen reserves are used in the formation of structural components during the growth of the seedling (ZIEGLER, 1995). Low temperatures can promote the deploy merization of carbohydrates, resulting in increased nitrogen and soluble sugars. Protein biosynthesis begins in the nucleus from the DNA transcription and translation processes. The production of this reserve compound occurs in the rough endoplasmic reticulum, being highly dependent on the use of amino acids (BEWLEY et al., 2013). The highest content of soluble proteins is interesting for the performance of seeds and seedlings, since, the level of protein can maintain relation with the greater vigor (HENNING et al., 2010).

The vigor is benefited by the deposition of proteins during the formation of the seeds, which are metabolized during the germinative process for the production of energy or hydrolyzed, occurring the release of amino acids. Amino acids are used 
for the synthesis of new proteins, which at high temperatures can be heat shock proteins (PESKE et al., 2012). Thus, the higher values of protein verified in seedlings under extreme temperatures, compared to $25^{\circ} \mathrm{C}$, allows to infer that the genotypes maintained under these conditions, presented higher demand for protein compounds or lower degradation of these compounds.

The amount of total amino acids observed in seedlings of the different genotypes was higher when analyzing the temperature of $15^{\circ} \mathrm{C}$ (Table 4). The total amino acids were similar in seedlings of the genotypes Carioquinha, IPR Tuiuiu and Guabiju, as well as in the temperature of $35^{\circ} \mathrm{C}$, among the five beans genotypes (Table 4).

The proteins can be hydrolyzed by various proteases resulting in the release of amino acids, while the peptidases act on the peptides and have as their product the formation of amino acids. Protein degradation allows the recycling of amino acids and prevents the synthesis of unwanted proteins to plant metabolism (BUCHANAN, 2015). The amino acid contents are influenced by the environment and the genotype, as well as the demand for protein compounds (TAIZ; ZEIGER, 2013).

The content of starch in seedlings, at $15^{\circ} \mathrm{C}$, did not show a significant difference among the genotypes (Table 4). At $35^{\circ} \mathrm{C}$, Tuiuiu IPR had the lowest starch content in relation to the other genotypes and the total soluble sugar levels at $15^{\circ} \mathrm{C}$ were similar among the genotypes. The temperature of $35^{\circ} \mathrm{C}$ caused an increase in the sugar content of beans seedlings of BRS Embaixador, Guabiju and Mouro genotypes, compared to the other genotypes. However, IPR Tuiuiu and Carioquinha showed no differences among the temperatures for this variable. 
Table 4. Total soluble amino acids (aa), total soluble proteins (SP), total soluble sugars (SS) and starch (SC) determined in seedlings of different beans genotypes under adverse germination temperatures. UFPel,

Pelotas, 2017.

Tabela 4. Aminoácidos solúveis totais (aa), proteínas solúveis totais (SP), açúcares solúveis totais (SS) e amido (SC) determinados em plantas de diferentes genótipos de feijão sob temperaturas adversas de germinação. UFPel, Pelotas, 2017.

\begin{tabular}{|c|c|c|c|c|c|c|}
\hline \multirow{2}{*}{ Genotypes } & \multicolumn{3}{|c|}{ Protein $\left(\mathrm{mg} \mathrm{g}^{-1} \mathrm{MF}\right)$} & \multicolumn{3}{|c|}{ Total amino acids ( $\left.\mathrm{mg} \mathrm{g}^{-1} \mathrm{MF}\right)$} \\
\hline & $15^{\circ} \mathrm{C}$ & $25^{\circ} \mathrm{C}$ & $35^{\circ} \mathrm{C}$ & $15^{\circ} \mathrm{C}$ & $25^{\circ} \mathrm{C}$ & $35^{\circ} \mathrm{C}$ \\
\hline BRS Embaixador & $124.43 a \mathrm{~A}^{1}$ & 46.37abC & $63.30 \mathrm{aB}$ & $14.63 \mathrm{bA}^{1}$ & $12.45 \mathrm{bB}$ & $11.77 \mathrm{aB}$ \\
\hline IPR Tuiuiú & $53.11 \mathrm{cA}$ & $22.05 \mathrm{cB}$ & $60.79 a A$ & 16.70abA & $17.52 \mathrm{aA}$ & $10.94 \mathrm{aB}$ \\
\hline Guabiju & $81.80 \mathrm{bA}$ & $42.03 a b B$ & $76.73 a A$ & 16.15abA & $12.47 \mathrm{bB}$ & $9.83 \mathrm{aC}$ \\
\hline Mouro & $52.59 \mathrm{cAB}$ & $40.79 b B$ & $64.56 \mathrm{aA}$ & $14.72 \mathrm{bA}$ & $13.41 \mathrm{bA}$ & $10.02 \mathrm{aB}$ \\
\hline Carioquinha & $58.79 \mathrm{cA}$ & $58.24 \mathrm{aA}$ & $72.05 a \mathrm{~A}$ & $17.33 a A$ & $13.50 \mathrm{bB}$ & $10.47 \mathrm{aC}$ \\
\hline \multirow[t]{3}{*}{ CV (\%) } & & 11.42 & & & 7.91 & \\
\hline & \multicolumn{3}{|c|}{ Starch (mg g $\left.{ }^{-1} \mathrm{MF}\right)$} & \multicolumn{3}{|c|}{ Soluble sugar ( $\left.\mathrm{mg} \mathrm{g}^{-1} \mathrm{MF}\right)$} \\
\hline & $15^{\circ} \mathrm{C}$ & $25^{\circ} \mathrm{C}$ & $35^{\circ} \mathrm{C}$ & $15^{\circ} \mathrm{C}$ & $25^{\circ} \mathrm{C}$ & $35^{\circ} \mathrm{C}$ \\
\hline BRS Embaixador & $0.2028 a A^{1}$ & $0.1786 \mathrm{bB}$ & $0.2576 a A$ & $51.11 \mathrm{aB}$ & $77.45 \mathrm{bB}$ & $105.74 a A$ \\
\hline IPR Tuiuiú & $0.1411 a A$ & $0.1525 \mathrm{bA}$ & $0.1415 \mathrm{bA}$ & $56.41 \mathrm{aA}$ & $67.56 \mathrm{bA}$ & $70.25 \mathrm{bA}$ \\
\hline Guabiju & $0.1503 a \mathrm{a}$ & $0.2282 \mathrm{bA}$ & $0.2315 a A$ & $54.84 a \mathrm{a}$ & $73.78 \mathrm{bAB}$ & 86.74abA \\
\hline Mouro & $0.1958 a B$ & $0.3083 a A$ & $0.2212 \mathrm{aB}$ & $64.63 a B$ & $120.12 \mathrm{aA}$ & $105.05 a A$ \\
\hline Carioquinha & $0.1371 \mathrm{aB}$ & $0.1630 \mathrm{bAB}$ & $0.2151 \mathrm{abA}$ & $78.17 \mathrm{aA}$ & $83.03 \mathrm{bA}$ & $71.86 \mathrm{bA}$ \\
\hline CV (\%) & & 16.34 & & & 16.80 & \\
\hline
\end{tabular}

${ }^{1}$ Médias seguidas da mesma letra, maiúscula na linha e minúscula na coluna, para cada variável resposta, não diferem entre si pelo teste de Tukey (0.05\%).

Within certain favorable temperature limits, the elevation of soluble sugar levels may be due to the breakdown of the starch into smaller molecules. Carbohydrates are an important source of energy for growth acting as a source of carbon skeletons for young tissues (MARENCO; LOPES, 2009).

The greater amount of total soluble sugars in association with the lower level of starch evidences more amount of carbohydrates available and readily usable by the seedling. Soluble sugars are essential for metabolism, development and many physiological and metabolic processes $(\mathrm{KOCH}, 1996$, KRAPP et al., 1993). In this sense, the increase in the amount of soluble sugars is determined by the breakdown of the starch molecule through reactions catalyzed by hydrolytic and debranching enzymes, releasing compounds of smaller size and easier to use (FERREIRA; BORGHETTI, 2009).

Starch is a reserve compound in higher plants, serving as an energy source for the initial development of the plant and as a product of its hydrolysis, maltose and glucose, which are present in both the amylose and deamylopectin fractions (BUCKERIDGE et al., 2004). In this process, in dicotyledons such as beans, during the metabolism of starch reversal, there is a tendency of accumulation of glucose$1-P$ or trioses- $P$ as final products of degradation, as well as activity of the enzyme 
starch phosphorylase in conjunct action with ana-amylase for the complete degradation of the compound (BUCKERIDGE et al., 2004).

The chemical composition of the seedlings in the five genotypes during germination varied according to temperature (Table 4). Increased protein content was observed at temperatures of $15^{\circ} \mathrm{C}$ and $35^{\circ} \mathrm{C}$ for most genotypes. Under stress, increased protein content plays a key role in the responses triggered by the limiting factor. The total amino acid content in the five genotypes was higher at the temperature of $15^{\circ} \mathrm{C}$ and the total starch and sugars content at $35^{\circ} \mathrm{C}$ in all genotypes (Table 4).

The differential performance in resumption of embryo growth, the amount of reserves allocated in the seedlings and their nature, are related to mechanisms of stress response (MITTLER; BLUMWALD, 2010). Chemical compounds stored in seed storage structures, whether carbohydrates or proteins, are used to produce energy in the respiratory process, which is intensified by the absorption of water during imbibition.

In the respiratory process, glycolysis is responsible for the rapid generation of energy at the beginning of the germinative process in both aerobic and anaerobic conditions, while the Krebs cycle and the electron transport chain aim to give continuity to the oxidation reactions of compounds with release of greater amount of energy. In general, carbohydrates are used to generate ATP while proteins and amino acids are also used as a source of nitrogen. Thus, for starch and proteins to be used for growth, they must be deployed in smaller molecules (FERREIRA; BORGHETTI, 2009).

\section{CONCLUSIONS}

The physiological characteristics germination and first germination count reveal higher magnitudes in seeds produced by genotypes BRS Embaixador, IPR Tuiuiú and Carioquinha.

For all genotypes, protein and amino acid levels were higher in seedlings submitted to lower temperatures.

The levels of starch and total soluble sugars are higher in seedlings produced at a temperature of $35^{\circ} \mathrm{C}$. 
Yield, physiological seed quality and chemical composition of seedlings are influenced by the agricultural crop and genotypes tested.

\section{ACKNOWLEDGMENTS}

The authors wish to thank the National Council for Scientific and Technological Development (CNPq) for the support and conception of the productivity scholarship in $2 \mathrm{~A}$ research level and wish to thank the Coordination of Improvement of Higher Education Personnel (CAPES), for the support.

\section{REFERENCES}

ALBRECHT, L. P.; BRACCINI, A. L.; ÁVILA, M. R.; SCAPIM, C. A.; BARBOSA, M. B.; STÜLP, M. Sementes de soja produzidas em época de safrinha na região oeste do estado do Paraná. Acta Scientiarum Agronomy, v.31, n.1, p.121-127, 2009. DOI: http://dx.doi.org/10.4025/actasciagron.v31i1.6638.

ÁVILA, M. R.; BRACCINI, A. L.; SCAPIM, C. A. Teste de comprimento de plântulas sob estresse hídrico na avaliação do potencial fisiológico das sementes de milho. Revista Brasileira de Sementes, v.29, n.2, p.117-124, 2007. DOI: http://dx.doi.org/10.1590/S0101-31222007000200016.

BRASIL. Ministério da Agricultura e Reforma Agrária. Regras para Análise de Sementes. Brasília: SNAD/CLAV, 2009. 398p.

BRUENING, G.; CRIDDLE, R.; PREISS, J.; RUDER, T. F. Biochemistry experiments. New York: J. Wiley, 1970. 314p.

BRADFORD, M. M. A rapid and sensitive method for the quantification of microgram quantities of protein utilizing the principle of protein dye binding. Analytical Biochemistry, v.72, p.246-254, 1976. DOI: 10.1006/abio.1976.9999

BUCKERIDGE, M. S.; SANTOS, H. P.; TINÉ, M. A.; AIDAR, M. P. M. Mobilização de Reservas. In: Germinação. Do básico ao aplicado. Alfredo Gui Ferreira \& Fabian Borgheti (Ed.). Artmed, Porto Alegre, 2004. 163-185p.

CLEGG, K. M. The application of the anthrone reagent to the estimation of search in cereals. Journal Science Food and Agriculture, v.7, n.23, p.40-44, 1956. DOI: https://doi.org/10.1002/jsfa.2740070108

CONAB. Acompanhamento da Safra Brasileira de grãos 2018/19. v.6, Décimo segundo levantamento. Setembro de 2019, 2018/2019.

CTSBF, Comissão Técnica Sul-Brasileira de Feijão. Informações técnicas para o cultivo de feijão na Região Sul brasileira. 2.ed. Florianópolis: Epagri. 2012. 157p. 
CREADY, R. M.; GUGGOLZ J, WENS H. S. Determination of start an amylases in vegetables. Analytical Chemistry, v.22, p.1156-1158, 1950. DOI: http://dx.doi.org/10.1021/ac60045a016

ECCO, M.; SANTOS, D. T.; POTTKER, V. L.; REUTER, R. J.; RICHARD, A.; LIMA, W. H.; BORSOI, A. Desempenho germinativo de sementes de feijoeiro, submetidas a temperaturas e métodos de condução. Revista cultivando o saber, v.10, n.4, p.421-434, 2017.

HENNING, F. A.; MERTZ, L. M.; JACOB JUNIOR, E. A.; MACHADO, R. D.; FISS, G.; ZIMMER, P. D. Composição química e mobilização de reservas em sementes de soja de alto e baixo vigor. Bragantia, v.69, n.3, p.727-734, 2010.

LACERDA, C. F.; CARVALHO, C. M.; VIEIRA, M. R.; NOBRE, J. G. A.; NEVES, A. L. R.; RODRIGUES, C. F. Análise de crescimento de milho e feijão sob diferentes condições de sombreamento. Revista Brasileira de Ciências Agrárias, v.5, n.1, p.18-24, 2010. DOI:10.5039/agraria.v5i1a485

LIZANA, C.; WENTWORTH, M.; MARTINEZ, J. P.; VILLEGAS, D.; MENESES, R.; MURCHIE, E. H.; PASTENES, C.; LERCARI, B.; VERNIERI, P.; HORTON, P.; PINTO, M. Differential adaptation of two varieties of common bean to abiotic stress. I. Effects of drought on yield and photosynthesis. Journal of Experimental Botany, v.57, n.3, p.685-697, 2006. DOI: 10.1093/jxb/erj062

MARCOS FILHO, J. Fisiologia de Sementes de Plantas Cultivadas. Piracicaba: Fealq. 2005. 495p.

MARCOS FILHO, J.; KIKUTI, A. L. P.; LIMA, L. B. Métodos para avaliação do vigor de sementes de soja, incluindo a análise computadorizada de imagens. R. Bras. Sementes, v.31, n.1, p.102-112, 2009. DOI: https://doi.org/10.1590/S010131222009000100012

MATHEUS, M. T.; LOPES, J. C. Temperaturas cardinais para a germinação de sementes de Erythrinavariegata L. Revista Brasileira de Sementes, v.31, n.3, p. 115-122, 2009. DOI: https://doi.org/10.1590/S0101-31222009000300013

MARENCO, R. A.; LOPES, N. F. Fisiologia vegetal: fotossíntese, respiração, relações hídricas e nutrição mineral. 3. ed. Viçosa: UFV, 2009. 468p.

MA, J.; HUANG, G. B.; YANG, D. L.; CHAI, Q. Dry matter remobilization and compensatory effects in various internodes of spring wheat under water stress. Crop Science, v.54, p.331- 339, 2014.

DOI: https://doi.org/10.2135/cropsci2013.03.0141

MITTLER, R.; BLUMWALD, E. Genetic engineering for modern agriculture: Challenges and perspectives. Annual R. P. Biol, v.61, p.443-462, 2010. DOI: 10.1146/annurev-arplant-042809-112116

MERTZ, L. M.; HENNING, F. A.; SOARES, R. C.; BALDIGA, R. F.; PESKE, F. B.; MORAES, D. M. Alterações fisiológicas em sementes de arroz expostas ao frio na 
fase de germinação. Revista Brasileira de Sementes, v.31, n.2, p.262-270, 2009. DOI: http://dx.doi.org/10.1590/S0101-31222009000200031

MÜLLER, L. E. Manual de Laboratório de Fisiologia Vegetal. Instituto Interamericano de Ciencias Agricolas de la O.E.A.. Turrialba, Costa Rica. 1964. $165 p$.

RAMALHO, M. A.P.; FERREIRA, D. F.; OLIVEIRA, A. C. Experimentação em genética e melhoramento de plantas. Lavras: UFLA. 2000. 326 p.

SILVA, V.R.; REICHERT, J.M.; REINERT, D.J. Variação na temperatura do solo em três sistemas de manejo na cultura do feijão. Revista Brasileira de Ciências do Solo, v.30, p.391-399, 2006. DOI: http://dx.doi.org/10.1590/S0100-06832006000300001

SHAO, H. B.; CHU, L. Y.; JALEEL, C. A.; ZHAO, C. X. Water-deficit stress-induced anatomical changes in higher plants. Comptes Rendus Biologes, v.331, p.215-225, 2008. DOI:10.1016/j.crvi.2008.01.002

THUZAR, M.; PUTEH, A. B.; ABDULLAH, N. A. P.; LASSIM. M. B. M.; JUSOFF, K. The effects of temperature stress on the quality and yield of soya bean [(Glycine max L.) Merrill.]. Journal Agriculture Science, v.2, n.1, p. 172-179, 2010. DOI: 10.5539/jas.v2n1p172

VANZOLINI, S.; ARAKI, C. A. S.; SILVA, A. C. T. M.; NAKAGAWA, J. Teste de comprimento de plântula na avaliação da qualidade fisiológica de sementes de soja. Revista Brasileira de Sementes, v.29, n.2, p.90-96, 2007.

ZIEGLER, P. Carbohydrate degradation during germination. In: Kigel J, Galili G (Ed.). Seed development and germination. New York: Marcel Dekker, 1995. p. 447474. 